(C) The Author(s), 2020. Published by Cambridge University Press on behalf of the British Institute of International and Comparative Law. This is an Open Access article, distributed under the terms of the Creative Commons Attribution licence (http://creativecommons.org/licenses/by/4.0/), which permits unrestricted re-use, distribution, and reproduction in any medium, provided the original work is properly cited.

\title{
POLYCENTRICITY AND POLYPHONY IN INTERNATIONAL LAW: INTERPRETING THE CORPORATE RESPONSIBILITY TO RESPECT HUMAN RIGHTS
}

\author{
ENRICO PARTITI* (D)
}

\begin{abstract}
Complex multi-actors and multi-level governance structures have emerged in areas that were traditionally exclusively the preserve of the State and treaty-making. The adoption of the United Nations Guiding Principles on Business and Human Rights (UNGP) affirmed a corporate responsibility to respect human rights to be implemented through human rights due diligence (HRDD), ie via management processes. The openended character of the UNGP generated the emergence of other soft instruments offering guidance to corporations in structuring HRDD. This contribution conceptualises the UNGP from the perspective of regulation as a principles-based exercise in polycentric governance reliant on regulatory intermediaries for interpretation. It then assesses the role of various sui generis normative instruments in providing interpretation to the UNGP and, how the presence of an additional layer of interpretative material contributes to the institutionalisation of responsible corporate conduct. The analysis of instruments drafted by international, nongovernmental and business organisations reveals both a decentralising tension between different intermediaries due to disagreements and divergence concerning the precise extent of corporate human rights responsibilities, as well as attempts to centralise the interpretation of the UNGP. The article concludes by recommending some caution towards the employment of polycentric governance regimes and their lack of centralised interpretive authority in this domain of international law and suggests possible ways to formally establish centralised interpretation.
\end{abstract}

Keywords: human rights, human rights due diligence, interpretation, polycentricity, United Nations Guiding Principles on Business and Human Rights, corporate responsibility to respect.

* Assistant Professor of Transnational Regulation and Governance, Tilburg University; Associate Researcher, T.M.C. Asser Institute, e.d.partiti@tilburguniversity.edu. The author would like to thank Nadia Bernaz, Stephanie Bijlmakers, Nikolas Rajkovic, the participants of Tilburg University's International Legal Incubator series and the two anonymous reviewers. All errors remain responsibility of the author alone. This contribution was written in the context of a research project that received funding from the European Research Council (ERC) under the European Union's Horizon 2020 research and innovation programme (Grant Agreement No 725798). 


\section{INTRODUCTION}

The unanimous adoption by the United Nations' Human Rights Council of the Respect, Protect, Remedy Framework ${ }^{1}$ designed by Harvard Professor John Ruggie, and its consequent operationalisation in the almost universally acclaimed United Nations (UN) Guiding Principles on Business and Human Rights (UNGP), ${ }^{2}$ illustrate the pivotal role that both informal norm-making processes $^{3}$ and private actors, including single corporations, have acquired in international law. ${ }^{4}$ While recognising and stigmatising the role of business in human rights violations across the globe, the UNGP framework seeks to leverage traditional internal corporate approaches to manage risks arising from the intersection of transnational corporate activities, regulation of global value chains, and human rights. Ruggie described the UNGP as a 'conceptual and normative framework establishing the parameters and perimeters of business and human rights as an international policy domain', ${ }^{5}$ with the aim of translating human rights into the processes that corporations employ to manage their risks. The UNGP therefore constitutes a testament to the increasingly frequent formal and informal use by public authorities of private actors, and their rules and standards, in the transnational pursuit of public goals ${ }^{6}$ and in the quest for an effective 'smart mix' of regulatory actors, instruments and techniques ${ }^{7}$ - especially in the field of human rights. ${ }^{8}$

The UNGP framework rests on three pillars establishing a State duty to protect against human rights abuses, matched by corporate responsibility to respect human rights, and the right of victims to have access to remedies. Human rights due diligence (HRDD) represents the most original feature of the UNGP. Part of a growing trend in international law focusing on procedural rather than substantive norms, ${ }^{9}$ the UNGP urges business to use HRDD and incorporate respect for human rights at the core of internal management processes and practice. HRDD 'comprises an ongoing

1 Human Rights Council Res. 8/7, UN Doc A/C/RES/8/7 (18 June 2008).

2 Human Rights Council, 'Guiding Principles on Business and Human Rights: Implementing the United Nations' "Protect, Respect and Remedy" Framework', A/HRC/17/31 (21 March 2011).

3 J Pauwelyn, R Wessel and J Wouters (eds), Informal International Lawmaking (Oxford University Press 2012).

4 A Peters, L Koechlin, T Förster and GF Zinkernagel (eds), Non-State Actors as Standard Setters (Cambridge University Press 2009). On corporations implementing and enforcing international law: J Butler, 'The Corporate Keepers of International Law' (2020) 114 AJIL 189.

5 JG Ruggie "Global Governance and "New Governance Theory": Lessons from Business and Human Rights' 20 Global Governance 8.

${ }^{6}$ See generally KW Abbott, P Genschel, D Snidal and B Zangl (eds), International Organisations as Orchestrators (Cambridge University Press 2015).

7 J Van Erp, M Faure, A Nollkaemper and N Philipsten (eds), Smart Mixes for Transboundary Environmental Harm (Cambridge University Press 2019) 9.

8 G De Búrca 'Human Rights Experimentalism' (2017) 111 AJIL 277.

9 H Krieger and A Peters (eds), Due Diligence in International Law (Oxford University Press 2020) forthcoming; N McDonald, 'The Role of Due Diligence in International Law' (2019) 68 ICLQ 1041. 
management process that a reasonable and prudent enterprise needs to undertake, in the light of its circumstances (including sector, operating context, size and similar factors) to meet its responsibility to respect human rights' ${ }^{10}$ In addition to the publication of a policy commitment and ensuring internal remedial mechanisms, HRDD should include human rights impact assessments, the integration of their outcomes in corporate procedures, the tracking of responses, and external communication. ${ }^{11}$

One of the peculiarities of the UNGP Framework is its consensual multistakeholder 'production process', ${ }^{12}$ it being the first instrument not drafted by States to be adopted by the UN Human Rights Council. In light of the need to obtain broad support-including from corporations - the UNGP are a framework not just characterised by limited options for enforcement, but also by indeterminacy in its substance. ${ }^{13}$ An approach characterised by 'principled pragmatism' and a pragmatic conception of the corporate responsibility to respect have led to broad principles being distilled on the basis of existing business practices through studies and multi-stakeholder engagement. Broad principles enhance flexibility for companies when giving meaning to HRDD and may facilitate compliance by stimulating the adoption of measures commensurate to the capabilities of each company and appropriate to the circumstances. ${ }^{14}$

The open-ended nature of the UNGP leaves corporations with a wide margin of discretion when deciding how to operationalise HRDD. On the one hand, the UNGP create, foster, and legitimise the activity of private actors such as corporations in the protection and enforcement of human rights. On the other, the UNGP provide only limited opportunities to constrain and guide their implementation by firms in practical contexts. Given the lack of clear guidance, corporations can exploit the open framework by making unsubstantiated claims to respect human rights or to dilute their responsibility. By design, the UNGP were established as an exercise in transnational polycentric governance, bringing together public governance, civil governance and corporate governance. ${ }^{15}$ Such a polycentric structure reflects not just the inherently pluralistic nature of the legal regulation of

\footnotetext{
${ }^{10}$ Office of the High Commissioner on Human Rights (2012) The Corporate Responsibility to Respect Human Rights. An Interpretative Guide. HR/PUB/12/02, 6.

11 UNGP Principle 17.

12 For a discussion and critique on the actual inclusiveness in the UNGP drafting: S Bijlmakers, 'Business and Human Rights Governance and Democratic Legitimacy: The UN "Protect, Respect and Remedy" Framework and the Guiding Principles' (2013) 26 Innovation 288.

13 S Deva and D Bilchitz 'The Human Rights Obligations of Business: A Critical Framework for the Future' in S Deva and D Bilchitz (eds), Human Rights Obligations of Business: Beyond the Corporate Responsibility to Respect? (Cambridge University Press 2013).

${ }_{14}$ S Bijlmakers, Corporate Social Responsibility, Human Rights and the Law (Routledge 2018) 48-52.

${ }^{15}$ Ruggie (n 5); JG Ruggie, 'The Social Construction of the UN Guiding Principles on Business and Human Rights' (2017) Corporate Responsibility Initiative Working Paper No 67. Cambridge, MA: John F. Kennedy School of Government, Harvard University.
} 
business and human rights which derives from a multiplicity of national, international, transnational hard and soft law, including private regulation. ${ }^{16}$ Ruggie hoped that the UNGP would mark the beginning of an orchestrating process between these three governance systems, in which the various institutions would align their respective instruments, further develop and bring about the interpretation and implementation of the UNGP in order to contribute to the fulfilment of human rights. ${ }^{17}$

The UNGP thus aims at instigating and supporting a process of bottom-up emergence and convergence of transnational regulatory regimes establishing businesses' human rights responsibility. They are just the starting point for a transnational process of assertion and refinement of the boundaries of corporate human rights responsibility by governmental organisations, private actors, transnational networks and interpretative communities. ${ }^{18} \mathrm{~A}$ global conversation over responsible business conduct is thus expected to remedy the indeterminacy of the UNGP. Many public and non-public actors are called on to help guide the application of the Principles to specific sectors, contexts of operation, and factual situations. The operationalisation of HRDD by corporations is mediated and influenced by the interpretive and implementing work of many actors, with many and varying goals.

This article analyses how selected actors, such as international organisations, non-governmental organisations (NGOs) and business associations, that have been formally and informally called on to implement and give meaning to the general principles in the UNGP and the boundaries of HRDD, have interpreted and transposed them into standards, guidelines and best practices. It explores the conditions and the processes through which the corporate responsibility to respect human rights is formed. ${ }^{19}$ It begins by sketching a framework for understanding the UNGP based on polycentric regulation, principles-based regulation and management-based regulation. The approach links the 'macro' level of international law and global governance structures with the 'micro' level of corporations, their practices and incentives. Drawing on literature concerning regulatory intermediaries, the article discusses the way in which key actors interpret, and to a lesser extent implement, the UNGP.

Studying the consequences of intermediation for the interpretation of the UNGP, and in particular the boundaries of HRDD, is of key importance when seeking to understand the corporate responsibility to respect human rights as set out in the UNGP, and its potential effectiveness. Norms are

16 C Rodríguez-Garavito, 'Business and Human Rights: Beyond the End of the Beginning' in C Rodríguez-Garavito (ed), Business and Human Rights: Beyond the End of the Beginning (Cambridge University Press 2017) 22.

17 JG Ruggie, 'Business and Human Rights: The Evolving International Agenda' (2007) 101 AJIL 819; Ruggie (n 5).

18 HH Koh, 'Is There a "New” New Haven School of International Law?' (2007) 32 YaleJIntlL $567-8$

19 G Shaffer and T Ginsburg, 'The Empirical Turn in International Legal Scholarship' (2012) 106 AJIL 1. 
generated and refined through the interactions and practices of different normative communities. ${ }^{20}$ At the early stages of the development of any regime actors interpreting general and broad rules have a significant impact on its evolution and on how it is to be applied. ${ }^{21}$ Deviations or misinterpretation of the UNGP have long-lasting repercussions for how corporations structure their HRDD and manage their human rights risks. ${ }^{22}$

Among the points left open in the UNGP Framework, ${ }^{23}$ this article focuses on the three categories for the 'attribution' 24 of negative human rights impacts to corporations which are identified in the UNGP: ie causation, contribution and direct linkage. These concepts are not straightforward to apply to the wide variety of contractual and factual situations characterising contemporary global value chains. In line with the polycentric nature of the UNGP, standards, guidelines and best practices drafted by international organisations, non-governmental organisations (NGOs) and business associations offer more precise frameworks for HRDD. However, as this article will show, the interpretations offered may also considerably deviate from the UNGP. This divergence exposes coordination challenges and a number of unconventional strategies have been adopted in order to 'steer' intermediaries' interpretation.

This contribution reflects on the appropriateness of the polycentric design of the UNGP and argues that polycentricity, an indispensable governance feature in the UNGP according to Ruggie, may hinder business responsibility to respect human rights. Polycentricity risks degenerating into polyphony, ie unavoidable divergences between equally valid interpretative approaches. While the absence of central authority, textual uncertainty and divergence in interpretation are well-known issues in international law, the UNGP have been deliberately designed to rely on, and embrace, broad principles and 'decentralised' interpretation via polycentricity as key vehicles through which to establish and advance a corporate responsibility to respect.

This article argues that such an approach has its drawbacks, as it is structurally open to divergence in interpretation. Divergence is particularly problematic where corporations have to operationalise provisions originating

20 PS Berman, 'Global Legal Pluralism' (2007) 80 SCalLRev 1155.

21 G Auld and S Renckens 'Rule-making Feedbacks through Intermediation and Evaluation in Transnational Private Governance' (2017) 670 Annals of the American Academy of Political and Social Science 93.

22 D De Felice 'Banks and Human Rights Due Diligence: A Critical Analysis of the Thun Group's Discussion Paper on the UN Guiding Principles on Business and Human Rights' (2015) 19 IJHR 321.

${ }_{23}$ Other crucial issues include which human rights corporations have to respect-a complex questions where human rights originally established as offering protection from States are involved - and what precise actions are required by corporations in 'enforcing' human rights with respect to other actors in the value chain to which they are linked.

24 These are conceptually different from those under the Articles on State Responsibilities for attribution of private conduct to the State. Draft Articles on Responsibility of States for Internationally Wrongful Acts, with commentaries. Yearbook of the International Law Commission (2001) vol II, Pt Two, 31, arts 5, 8 and 11. 
in soft law, and it threatens the establishment of a clear and uncontested corporate responsibility to respect human rights, and the boundaries thereof. This article suggests that 'centralised' forms of interpretation - more in line with international law instruments - are necessary for the establishment of a corporate responsibility to respect. It will consider whether more centralised interpretative approaches are already emerging as a result of the process to adopt a binding treaty on Business and Human Rights which is currently taking place.

This article is structured as follows. Section II explores the transnational regulatory governance resulting from the UNGP through a theoretical framework synthesising polycentric governance, principles-based regulation, management-based regulation and the regulator-intermediary-target (RIT) model. It discusses HRDD and its ongoing interpretation, stressing the importance of there being substantive clarity concerning the 'attribution' of impacts to a corporation. This framework allows the identification of challenges connected to the governance structures informally established around the UNGP concerning interpretive functions, and their consequences for the operationalisation of HRDD by businesses. Section III discusses the interpretative work found in public and private standards and guidelines concerning attribution. It assesses the International Organisation for Standardisation (ISO) 26000 standard, relevant sectoral guidance documents by the Organisation for Economic Cooperation and Development (OECD), the International Finance Corporation's (IFC) Performance Criteria, the International Labour Organisation (ILO) tripartite Declaration of Principles concerning Multinational Enterprises and Social Policy, and guidance provided by the Thun Group of Banks, an association of private financial entities. The section identifies a number of tensions and divergences with the UNGP, explicit attempts to dilute their obligations, and attempts by some of these bodies to retain interpretive control. Section IV reflects upon the challenges of a polycentric approach for the development of a corporate responsibility to respect human rights, as well as possible alternatives. Section V concludes.

\section{THE REGULATORY GOVERNANCE OF THE UNGP AND HRDD}

This section explores the conceptual and theoretical background to both the UNGP framework and HRDD with reference to scholarship on transnational regulation. From a regulation perspective, studying an international (soft) law instrument and the complex governance structures it has generated exposes potential challenges resulting from the architecture of the UNGP and the characteristics of HRDD that have so far been overlooked. At the same time, it allows an appraisal from a different perspective to that of international law, of the implications of replacing traditional international law instruments with complex multi-level governance structures reliant on soft law. 


\section{A. The Regulatory Effects of HRDD}

As described in the UNGP, HRDD differs from corporate social responsibility (CSR) because it constitutes a global and overarching expectation of all corporations, rather than being a voluntary undertaking in a specific field and in respect of a restricted number of beneficiaries. ${ }^{25}$ In contrast to a voluntary understanding of CSR, reflecting various economic and non-economic motivations, the conceptualisation of corporate responsibility advanced by the UNGP is grounded in case law and business practices which accepts and institutionalises a 'duty of care' towards affiliates. ${ }^{26}$ This responsibility, however, does not just encompass the (self) regulation of corporate activities between a mother company and its subsidiaries, but extends to all human rights impacts stemming from all commercial and non-commercial relations that a corporation has, or may have, with other business entities (including governments), employees, customers, and human rights holders affected by its operations. ${ }^{27}$ Companies have a considerable margin when determining how to structure their HRDD. However, the manner in which it is operationalised identifies the scope of its human rights responsibility, and determines its response to human rights risks in a way that not only affects human rights holders but also other business entities, and (at least in theory) forms the basis for future remediation. ${ }^{28}$

The UNGP require corporations to seek to identify, prevent, and use their leverage to mitigate human rights impacts directly linked to their operations, as well as requiring remediation in specific situations. UNGP 13 acknowledges that corporations can be associated with adverse human rights impacts, both through their own activities, or as a result of their business relationships. In the first case, corporations are considered to have caused negative impacts, and therefore have to take the necessary steps to cease or prevent such impacts through HRDD and to offer remediation. Where a corporation generates adverse human rights impacts through its commercial relations, two scenarios are possible. A corporation contributes to negative human rights impacts where impacts are co-generated either with another entity, or via a third entity with which it has a business relationship. In this case, the enterprise should take the necessary steps to cease or prevent its contribution, and in addition use its leverage to mitigate any remaining impacts. In the second scenario it is possible to trace a direct link between adverse impacts and a corporation's operations, products or services through its commercial relations with other companies. The UNGP acknowledge that

\footnotetext{
25 United Nations, Office of the High Commissioner on Human Rights, 'Frequently Asked Questions about the Guiding Principles on Business and Human Rights' (2014) 9-10.

${ }^{26}$ R Mares, 'Global Corporate Social Responsibility, Human Rights and The Law: An Interactive Regulatory Perspective on the Voluntary-Mandatory Dichotomy' (2010) 1 TLT 221.

27 UNGP Principle 11.

28 B Santoso, "Just Business": Is the Current Regulatory Framework an Adequate Solution to Human Rights Abuses by Transnational Corporations?' (2017) 18 German Law Journal 549.
} 
this scenario is the most complex both in terms of identification and in terms of determining appropriate action, as it may involve entities with which the company has no direct contractual relationship, such as the supplier of a supplier. Generally, no remediation is required, and the company should use its leverage to prevent or mitigate adverse impacts. ${ }^{29}$ This scenario is the most far reaching, since it potentially stretches upstream into a company's value chain.

Through the concepts of 'contribution' and, especially, of 'direct linkage', corporations are required to act as a transnational value chain (self)regulator/ enforcer in the field of human rights. ${ }^{30}$ Corporations are called on to design procedures to monitor their human rights impacts and ensure that international human rights norms are respected in their activities and business relations throughout the entirety of their supply chain. As regards 'contribution' and 'direct link', this includes strategies to engage with other entities, to exercise leverage, and ultimately to 'sanction' non-complying suppliers through disengagement. Internally, HRDD is operationalised by assessing actual and potential human rights impacts, integrating and acting upon findings, tracking responses, and communicating how such impacts are addressed. ${ }^{31}$ Such processes should be fully integrated. ${ }^{32}$ HRDD has, therefore, many similarities with procedural and management-based approaches to regulation, requiring corporations to engage in their own planning, information-collection and internal rule-making. ${ }^{33}$

\section{B. Principles-Based Regulation}

The operationalisation of HRDD by corporations must be discussed in the light of its origins, being embedded within the UNGP which has a principles-based nature. Principles-based regulation (PBR) encompasses a variety of techniques. ${ }^{34}$ PBR involves regulators communicating their goals via broad principles, while regulatees are required to engage in self-reflection and develop internal management-based regulation which ensures that the desired goals are met. ${ }^{35}$ Proponents of PBR argue that broad principles are more successful than detailed rules in achieving effectiveness and congruence with overarching legislative purposes. ${ }^{36}$ The transposition of these 'new governance' techniques to the transnational stage of regulation of the global

${ }^{29}$ UNGP Principle 19 and commentary.

30 GA Sarfaty, 'Shining Light on Global Supply Chains' (2015) 56 HarvIntlLJ 419.

${ }^{31}$ UNGP Principle 17.

32 UNGP Principle 19.

33 E Bardach and R Kagan, Going by the Book: The Problem of Regulatory Unreasonableness (Temple University Press 1982) 224.

${ }_{34}$ J Black, 'Paradoxes and Failures: New Governance Techniques and the Financial Crisis' (2012) 75 MLR 1037.

35 J Black, 'Forms and Paradoxes of Principles-Based Regulation' (2008) 3 CMLJ 430.

${ }^{36}$ V Di Lorenzo, 'Principles-Based Regulation and Legislative Congruence' (2012) 45 NYUJLeg\&Pol 46. 
commons is not a new phenomenon. ${ }^{37}$ As noted by Ruggie, the UNGP extend this approach to the field of business and human rights. ${ }^{38}$ Similarly to PBR, the UNGP are grounded on a broad normative, qualitative, and purposive principle that corporations should generally respect human rights in their activities. ${ }^{39}$ To meet this goal, corporations are required to adopt, design and continuously evaluate and update managerial risk-based processes. ${ }^{40}$ This approach shifts the responsibility to design regulatory solutions to the regulated entities, which are required to determine what needs to be done in order to meet the objectives provided by the norms in question. ${ }^{41}$ As has been said, the UNGP do not provide concrete guidance for corporations concerning the implementation of their HRDD responsibilities, leaving considerable leeway as regards their practical application.

However, requiring corporations to engage in critical learning - such as acquiring information concerning human rights impacts, and to 'know and show' that compliance with human rights occurs ${ }^{42}$ - is not sufficient to meet the goals of the regime. Regardless of the tools of enforcement, and to minimise recourse to sanctions and litigation, it is necessary to ensure that the correct tasks are performed, and in the proper manner. When engaging in PBR, structures should be established which do not rely on the assumption that corporations have both the incentives and the capacities to properly implement the principles and manage their risks. ${ }^{43}$ It is of fundamental importance that clear goals and outcomes are communicated. ${ }^{44}$ Ambiguity can provide justifications for undesirable behaviour. ${ }^{45}$ The lack of a precise and shared understanding of how principles should be interpreted and operationalised hinders the achievement of the goals of the regime and compliance with those goals. ${ }^{46}$ Crucial elements which determine the effectiveness of PBR are the mechanisms and actors that add content to the principles via interpretation, ${ }^{47}$ and further the understanding of both regulators and regulated entities. ${ }^{48}$

37 KW Abbott and D Snidal, 'The Governance Triangle: Regulatory Standards Institutions and the Shadow of the State' in W Mattli and N Woods (eds), The Politics of Global Regulation (Princeton University Press 2009) 44-88. $\quad 38$ Ruggie (n 5). $\quad 39$ UNGP Principle 11.

${ }^{40}$ UNGP Principles 15 and $17 . \quad 41$ Black (n 35) 443.

42 JG Ruggie and JF Sherman 'The Concept of "Due Diligence" in the UN Guiding Principles on Business and Human Rights: Reply to Professors Bonnitcha and McCorquodale' (2017) 28 EJIL 921-8. $\quad{ }_{43}$ Black (n 34) 1062-3. 44 Black (n 35) 426.

${ }^{45}$ N Mazar, O Amir and D Ariely, 'The Dishonesty of Honest People: A Theory of Self-Concept Maintenance' (2008) 45 Journal of Marketing Research 633.

${ }^{46}$ C Parker "The "Compliance" Trap: The Moral Message in Regulatory Enforcement' (2006) 40 L\&Soc’yRev 609.

${ }^{47}$ CL Ford, 'New Governance, Compliance and Principles-Based Securities Regulation' (2008) AmBusLJ 37.

48 J Zeitlin, 'Introduction' in J Zeitlin (ed), Extending Experimentalist Governance? The European Union and Transnational Regulation (Oxford University Press 2015) 1-19. 


\section{Intermediaries as (More Than) Interpretative Gap-Fillers in a Polycentric Governance Structure}

In principles-based regimes, interpretation and implementation are blurred. ${ }^{49}$ When broad principles are involved, giving meaning and giving effect to them overlap considerably, but remain separate functions. In this article 'interpretation' refers to providing meaning to constructs in the UNGP, whereas 'implementation' refers to their transposition into standards and procedures for corporations to use. This latter function arguably has fewer normative implications than the former. Corporate 'operationalisation' refers to the actions and choices taken by businesses when integrating due diligence into their daily processes and operations.

PBR may de-centralise interpretation to several public and private actors, soft law and non-soft law instruments. These features characterise a 'polycentric' PBR structure, where many actors participate in an evolutionary and iterative manner in the co-constitution of a legal regime. ${ }^{50}$ Since the Working Group on Business and Human Rights in the Office of the High Commissioner for Human Rights does not have the mandate to adopt authoritative interpretations of the UNGP, ${ }^{51}$ the open nature of the Principles has spurred a number of private and public actors to elaborate on their meaning and their specific application. ${ }^{52}$ This accords with Ruggie's strategy of dissemination and implementation in cooperation with international and national bodies and stakeholder groups, including business itself, in the hope of achieving a high degree of coherence and alignment with the UNGP. ${ }^{53}$ The interpretation of key HRDD provisions takes place through soft-law instruments drafted by a variety of organisations and entities in the form of standards, guidance, and best practices. These actors can be considered as intermediaries, ie entities acting, directly or indirectly, in conjunction with a regulator or a regulatory regime to affect the behaviour of those targeted by the UNGP. ${ }^{54}$ Intermediaries are needed because of their expertise. They interpret and clarify the principles, as well as adapting them to the specific circumstances of a given industry, country, or sector. Intermediaries may be created or activated by the rule-maker in order to expand regulatory capacity - such as providing interpretation in a PBR regime. They may also emerge spontaneously, with the express purpose of pursuing organisational

\footnotetext{
49 LB Solum, 'The Interpretation-Construction Distinction' (2010) 27 Constitutional Commentary 95 .

${ }_{50}$ Black (n 35) 428.

${ }_{51}$ Resolution A/HRC/RES/35/7 Adopted by the Human Rights Council on 22 June 2017.

52 K Buhmann, 'Business and Human Rights: Understanding the UN Guiding Principles from the Perspective of Transnational Business Governance Interactions' (2015) 6 TLT 399.

53 JG Ruggie and T Nelson, 'Human Rights and the OECD Guidelines for Multinational Enterprises: Normative Innovations and Implementation Challenges' (2015) Corporate Social Responsibility Initiative Working Paper No 66, Cambridge, MA: John F. Kennedy School of Government, Harvard University.

${ }^{54} \mathrm{KW}$ Abbott, D Levi-Faur and D Snidal, 'Theorising Regulatory Intermediaries: The RIT Model' (2017) 660 AnnalsAmAcadPol\&SocSci 19.
} 
goals, or even of influencing policy goals to their advantage, ${ }^{55}$ and operate independently of each other. ${ }^{56}$

Open-ended Guiding Principles with a broad scope of application have motivated other actors to contribute to their interpretation. One of the overarching purposes of the UNGP is to coordinate and align existing tools. Organisations whose work intersects with that of business and human rights, such as the OECD and ISO, have amended their standards, and other actors-including entities not necessarily previously involved with human rights impacts, such as business organisations-have also offered interpretation. A sort of 'spontaneous interpretation' has been stimulated under the UNGP in which: i) there are no barriers to the provision of interpretation, and ii) no consequences stem from following one interpretative approach over another. Regardless of whether it originates from international organisations such as the OECD, ISO, IFC or ILO, or from business associations and NGOs, these interpretative functions can involve drafting new instruments or amending existing instruments to reflect the UNGP.

Ideally, intermediaries enhance trust and dialogue between participants to a legal regime. They may, however, operate according to goals which are not aligned to those of the legislator or the regime at hand. This occurs where intermediaries are linked to targets, or where the targets act as intermediaries. Deliberative processes within intermediaries may also spontaneously lead to different outcomes than those achieved by other institutions. While all activities exercised by the intermediaries are not merely technical but have considerable normative implications, ${ }^{57}$ normativity becomes most noticeable when interpreting broad principles. Intermediaries play a vital function in the initial establishment and further development of regimes based on openended principles. ${ }^{58}$ However, the polycentric approach of the UNGP fails to recognise that a typical functional challenge of polycentric regimes is ensuring coordination between the intermediaries at the 'poles' of the regime. A central focus of authority is lacking, and the organisations within the regime (in our case those providing interpretation) whilst connected, act independently of each other. ${ }^{59}$ Particular challenges are faced by regimes lacking a clearly identified interpreter of the principles. For a polycentric regime to be effective, an overarching shared system for conflict resolution between the poles and disputes over interpretation must be present. ${ }^{60}$ In spite of its formal

\footnotetext{
55 A Marx and J Wouters, 'Rule Intermediaries in Global Labour Governance' (2017) 660 AnnalsAmAcadPol\&SocSci 189.

56 T Havinga and P Verbruggen, 'Understanding Complex Governance Relationships in Food Safety Regulation: The RIT Model as a Theoretical Lens' (2017) 660 AnnalsAmAcadPol\&SocSci 73.

57 KW Abbott, D Levi-Faur and D Snidal, 'Enriching the RIT Framework' (2017) 660 AnnalsAmAcadPol\&SocSci 280-8.

59 J Black, 'Constructing and Contesting Legitimacy and Accountability in Polycentric Regulatory Regimes’ (2008) 2 Regulation \& Governance 140.

60 J Van Zeben, 'Polycentricity as a Theory of Governance' in J Van Zeben and A Bobic (eds), Polycentricity in the European Union (Cambridge University Press 2019) 24.
} 
nature as international soft law, a formalised process defining how, and by whom the UNGP should be interpreted is still lacking.

The actors providing interpretation, however informal their relation with the UNGP is, enjoy considerable power in defining the rules of responsible business conduct. ${ }^{61}$ In polycentric regimes, the effects of intermediaries' work are considerable and it becomes difficult to identify the principal rule-maker. Rules emerge, are refined, and solidify from interactions between different actors in various institutional settings. ${ }^{62}$ If actors embrace and spread a consistent understanding of human rights business responsibility, a limited process of constitutionalisation emerges, in so far as it becomes harder for corporations to evade certain norms or to engage in certain behaviour. ${ }^{63}$ In this context, the authority of a rule is not linked to a single rule-maker or legislator; rather it increases over time on the basis of its general acceptance. ${ }^{64}$ The notion of network authority matters for the UNGP and the intermediaries around them because it addresses the lack of a single and formally binding interpretive and implementing mechanism. The intermediaries at the 'poles' of a polycentric system, regardless of their capacity to draft binding norms, increase over time the acceptance and authority of both the general principles in the UNGP and the responsibility to respect. This process takes place through the acceptance of their rule interpretation by network participants and, ultimately, the companies adopting HRDD.

\section{Substantive Indeterminacy in the UNGP and Its Consequences}

Refining the meaning of the UNGP, and especially HRDD, is particularly important since current corporate understandings of human rights, and the consequent scope of responsibility, vary greatly. ${ }^{65}$ Arguably, this difficulty in understanding possible human rights impacts is traceable to the UNGP' reference to international human rights instruments which were drafted with States in mind as the primary duty-bearers. In principle, any recognised international human right can be negatively impacted by corporations. ${ }^{66}$ The transposition of these instruments to economic actors results in

61 W Mattli and J Seddon, 'New Organisational Leadership: Nonstate Actors in Global Economic Governance’ (2015) 6 Global Policy 266.

62 TD Lytton, 'The Taming of the Stew: Regulatory Intermediaries in Food Safety Governance' (2017) 660 AnnalsAmAcadPol\&SocSci 89. See also N Krisch, 'Liquid Authority in Global Governance' (2017) 9 International Theory 237.

63 R Schmidt, Regulatory Integration across Borders: Public-Private Cooperation in Transnational Regulation (Cambridge University Press 2018) 149.

${ }^{64}$ O Perez and O Stegmann, 'Transnational Networked Constitutionalism' (2018) 45 JL\&Soc'y S135.

65 LJ Obara, "What Does This Mean?" How UK Companies Make Sense of Human Rights' (2017) 2 BHRJ 249.

${ }^{66}$ UNHRC, The Corporate Responsibility to Respect Human Rights: An Interpretative Guide (2012) 13. 
extremely complex conceptual problems which should not be glossed over. ${ }^{67}$ In order to effectively assign to corporations the responsibility to respect human rights, the boundaries of such responsibilities should be clear and entail as little discretion as possible. ${ }^{68}$

Even where human rights responsibilities can be easily transplanted into other contexts, there are many situations where it is difficult to determine whether corporations contribute, are directly linked, or are not linked to human rights impacts. A key element in need of refinement concerns the 'attribution' of negative impacts to a corporation, and in particular impacts brought about by the activities of other economic entities. When is a corporation connected to a negative human rights impact? While the category of causing human rights impacts is relatively straightforward, the concepts of contribution and direct link are less clear. Would a bank, through a loan to a client, cause human rights violations, contribute, or be directly linked to negative impacts brought about by the actions of its client? The limits of a direct link to a negative impact also need to be interpreted. Would a corporation be directly linked to human rights violations committed by a second-tier supplier or, even more remotely, by those who supply its secondtier supplier? Would a social network be contributing or be directly linked to bullying and child abuse committed by its users through its platforms?

These interpretative challenges in the operationalisation of the UNGP are far from theoretical. The UNGP provide that human rights expectations should be set out in a corporate statement of policy. This should also stipulate the enterprise's human rights expectations of its business partners and other parties directly linked to its operations, products or services. ${ }^{69}$ This provides the starting point from which the enterprise defines and leverages respect for human rights in these relationships, should this be necessary. ${ }^{70}$ If it is unclear that these expectations regarding human rights are a firm policy of the enterprise, they can easily become 'negotiable' and be sidelined. Recent benchmarking in corporate human rights practices has highlighted that the operationalisation of HRDD proceeds very slowly due to limited capacity to establish appropriate internal processes in the area of human rights. ${ }^{71}$ Even benchmarking initiatives themselves structurally fail to include the voices of those impacted. ${ }^{72}$ Empirical studies also indicate that companies face

${ }^{67}$ S Deva, 'Treating Human Rights Lightly: A Critique of the Consensus Rhetoric and the Language Employed by the Guiding Principles' in Deva and Bilchitz (n 13) 88.

68 DJ Karp, Responsibility for Human Rights, Transnational Corporations in Imperfect States. (Cambridge University Press 2014) 54; LL Fuller, The Morality of Law (Yale University Press 1969).

69 UNGP Commentary to Principle 13.

${ }^{70}$ Office of the High Commissioner for Human Rights, The Corporate Responsibility to Respect Human Rights: An Interpretative Guide (2012) HR/PUB/12/02.

${ }^{71}$ Corporate Human Rights Benchmark, 'Key Findings 2017. Available at $<$ https://www. corporatebenchmark.org/sites/default/files/2017-03/CHRB_Findings_web_pages.pdf >.

72 R Maher, 'De-contextualized Corporate Human Rights Benchmarks: Whose Perspective Counts? See Disclaimer' 5 BHRJ 156. 
difficulties in identifying human rights affected by their activities and in structuring specific components of HRDD. ${ }^{73}$ The continuing lack of guidance on how to interpret the UNGP remains a key challenge in their implementation. ${ }^{74}$ Corporations may thus exploit their open-ended nature in HRDD processes to strategically dilute their human rights responsibility, ${ }^{75}$ or approach it as a box-ticking exercise. ${ }^{76}$ Similar to other forms of management-based regulation, HRDD is exposed to the risk of resulting in empty proceduralisation lacking clear definitions, boundaries and goals. ${ }^{77}$ Without an unequivocal framework for interpretation, minimalistic and watered-down implementation of HRDD is a tangible risk. Corporate conceptualisations of compliance, even if misaligned with the UNGP, may then be accepted as fully lawful by courts and judges. ${ }^{78}$

\section{POLYCENTRIC INTERPRETATIONS OF THE UNGP}

The adoption of the UNGP stimulated a proliferation of standards, best practices and guidance documents. International organisations active in international standardisation such as the OECD, ISO and IFC, have all enacted instruments incorporating the UNGP and in particular the concept of HRDD, or have amended previous instruments in order to accommodate the framework. ${ }^{79}$ NGOs, think tanks, business organisations and even management consultancies have also contributed to this global regulatory conversation ${ }^{80}$ by drafting best practices and guidance documents offering interpretations of the UNGP. The majority of these instruments provide operational guidance by focusing on the procedural elements of HRDD, therefore addressing only marginally the substantive issues in need of interpretation flagged above. This section addresses the discrepancies between the interpretations of the categories of attribution in the UNGP in key standards drafted by three leading international organisations: the OECD Guidelines for Multinational Corporations, and in particular some of its Due Diligence Guidance documents; ISO 26000 standard, and the IFC Sustainability Principle and Performance Standards. The section also touches upon the ILO Declaration of Principles concerning Multinational Enterprises and Social Policy. It then addresses explicit challenges to the content and approach of the UNGP such as that raised by the Thun Group, an association

\footnotetext{
${ }^{73}$ K Salcito and M Wielga, 'What Does Human Rights Due Diligence for Business Relationships Really Look Like on the Ground?' (2018) 3 BHRJ 113.

74 Sarfaty (n 30) 448-9.

75 Santoso (n 28).

76 Working Group on the issue of human rights and transnational corporations and other business enterprises, 'The Report of the Working Group to the General Assembly on the issue of human rights and transnational corporations and other business enterprises' A/73/163 (16 July 2018) 8ff.

77 J Black, 'Proceduralising Regulation: Part 1' (2000) 20 OJLS 598.

78 LB Edelman, SR Fuller and I Mara-Drita, 'Diversity Rhetoric and the Managerialisation of Law' (2001) 106 AmJSoc 1589.

80 J Black, 'Regulatory Conversations' (2002) 29 JL\&Society 163.
} 
of financial entities. Finally, the section highlights attempts to influence the interpretative poles by actors as diverse as the UN Human Rights Council, Ruggie himself, and Shift, an NGO established by Ruggie with the purpose of contributing to the implementation of the UNGP.

\section{A. Divergence between International Standards and the UNGP}

The OECD, ISO, IFC and ILO are four crucial international organisations whose standard-setting work is essential for interpreting the UNGP and their successful embedding in business practices. Remarkably, standards drafted by these organisations may qualify as 'international standards' under international economic law, a status that grants them a strong normative claim and requires States to use them in regulation where necessary and possible. ${ }^{81}$ While operating independently and with distinct goals from those pursued by the UNGP, the work of these organisations has obvious intersections and synergies with corporate responsibility. To varying extents, however, their standards display discrepancies with the UNGP approach to the attribution of human rights impacts. This should not detract from the overall successful acceptance of the broader ideas behind the UNGP, their transposition in several instruments, and the progress made in their implementation and clarification. ${ }^{82}$ These differences, nonetheless, expose the practical difficulty in aligning approaches to key elements which are crucial to their full effectiveness.

The OECD was the first multilateral organisation concerned with the regulation of multinational corporations. Its 1976 Guidelines for Multinational Corporations (OECD Guidelines) are among the oldest set of international standards for business conduct. The Guidelines are a key instrument in the governance of transnational corporate conduct through a multi-level and mediation-based dispute resolution mechanism between corporations and human rights victims, through a system of National Contact Points (NCPs) ${ }^{83}$ Even if focusing on mediation and good offices, the NCPs are an important mechanism through which a 'jurisprudence' on business and human rights and HRDD can be developed globally based on their interpretation of the Guidelines in so-called 'specific instances', ie disputes concerning a corporation's implementation of the Guidelines. ${ }^{84}$ It is therefore particularly important that the Guidelines themselves are aligned to the UNGP. Their 2011 revision took place in parallel with the development of the UNGP and, on the basis of input from the UN Special Representative for

81 See art 2.4 of the World Trade Organisation's Technical Barriers to Trade (TBT) Agreement.

${ }^{82}$ Buhman (n 52) 429.

83 G Schuler, 'Effective Governance through Decentralised Soft Implementation: The OECD Guidelines for Multinational Enterprises' in A von Bogdandy et al. (eds), The Exercise of Public Authority by International Institutions (Springer Verlag 2008) 197.

${ }^{84}$ OECD, OECD Guidelines for Multinational Enterprises (OECD Publishing 2011) 83. 
Business and Human Rights, incorporates a revised human rights chapter which the OECD considers to be in line with the UNGP.

The OECD Guidelines adopt the concept of due diligence and apply it to human rights and other areas which they cover. ${ }^{85}$ The most elaborate discussion of HRDD is, however, not in the OECD Guidelines, but in their implementing Guidance documents transposing due diligence to specific sectors and their risks. Examples include the agricultural, ${ }^{86}$ mineral,${ }^{87}$ and garment and footwear ${ }^{88}$ supply chains. In May 2018 the OECD also published a general Guidance focusing on human rights due diligence across sectors. ${ }^{89}$ These standards contribute positively to the implementation of HRDD by offering a common understanding of due diligence processes and related terminology. ${ }^{90}$ In addition, they make recommendations to companies on how to implement due diligence in their value chains and incorporate HRDD in management systems and procedures. Guidance documents are drafted following a multi-stakeholder approach overseen by the OECD Working Party on Responsible Business Conduct, with the involvement of non-OECD countries and representatives from business, trade and civil society.

A second important organisation providing interpretation and implementation of the UNGP, and in particular in embedding HRDD in corporate management standards is the ISO. The ISO is a non-State industrydriven organisation made up of national (mostly private) standard-setting bodies. Its core-business standard-setting work relates to technical and interoperability standards. An increasing number of standards drafted by the ISO are in the form of audible management systems standards. Management systems standards integrate public policy goals, such as environmental protection and health and safety, into corporate procedures. ISO 26000 is the ISO's first foray in the field of sustainability, human rights and corporate responsibility. ${ }^{91}$ It was the product of extensive consultation with other organisations and stakeholders not routinely involved in ISO work, including the ILO, the OECD and the UN Global Compact. ${ }^{92}$ However, ISO 26000 does not extend the management systems standards approach to the domain of human rights and sustainability, both by not being certifiable and by not

\footnotetext{
85 Employment and industrial relations, environment, bribery, consumer interest, technology transfer, competition and taxation.

${ }^{86}$ OECD/FAO, OECD-FAO Guidance for Responsible Agricultural Supply Chains (OECD Publishing 2016).

87 OECD, OECD Due Diligence Guidance for Responsible Supply Chains of Minerals from Conflict-Affected and High-Risk Areas (3rd edn, OECD Publishing 2016).

88 OECD, OECD Due Diligence Guidance for Responsible Supply Chains in the Garment and Footwear Sector (OECD Publishing 2017).

${ }^{89}$ OECD, Due Diligence Guidance for Responsible Business Conduct (OECD Publishing 2018).

90 OECD, OECD Due Diligence Guidance for Responsible Supply Chains in the Garment and Footwear Sector (OECD Publishing 2017) Foreword, 3.

91 ISO, ISO 26000 Guidance on Social Responsibility (2010) ISO/FDIS 26000:2010(E).

92 Schmidt (n 63) 105-53.
} 
identifying actual management processes, as do other ISO management standards. ${ }^{93}$

The third key document is the IFC Performance Standards on Environmental and Social Sustainability. ${ }^{94}$ This adopts the IFC's (the private-sector lending arm of the World Bank) risk management approach to project financing. ${ }^{95}$ The relevance of the IFC standards is magnified exponentially through their reference in the Equator Principles, ${ }^{96}$ the instrument most frequently used by financial corporations to ensure responsibility in project financing. Project financing presents many opportunities to embed human rights considerations into corporate operations, such as the adoption of environmental and social management systems identifying and mitigating risks and improving performance that incorporate features of HRDD as defined in the UNGP. ${ }^{97}$

Finally, the ILO's work concerning labour rights also touches upon the subject matter of the UNGP. The ILO tripartite Declaration of Principles concerning Multinational Enterprises and Social Policy ${ }^{98}$ is a prime example. The Declaration sets out principles for governments, employers, workers and multinationals for measures furthering social progress and responsible workplace practices. The Declaration is particularly relevant as it is the only ILO instrument providing readily implementable guidance to enterprises on matters connected to social policy and inclusive, responsible and sustainable practices in the workplace. ${ }^{99}$ It is thus an additional vehicle through which HRDD concepts can be interpreted in the context of labour rights.

While many aspects of these instruments are in line, if not with the language, at least with the broad spirit of the UNGP, a careful analysis shows that they do not always fully align. While not all Guidance documents at the OECD level explicitly address the issue of attribution, the Garment and Footwear Guidance seems to tackle it by introducing variations to the UNGP approach. According to the Guidance, an enterprise contributes to negative human rights impact if the actions of the enterprise cause, facilitate or incentivise another entity to cause adverse impacts. However, a significant qualification is introduced, ie that such contribution must be substantial. Neither the UNGP nor other UN official publications on the UNGP mention the concept of substantial contribution. The subject is only touched upon in discussions

93 S Bijlmakers and G van Calster, "'You'd be Surprised How Much It Costs to Look This Cheap!" A Case Study of ISO 26000 on Social Responsibility' in P Delimatsis (ed), The Law, Economics and Politics of International Standardisation (Cambridge University Press 2015) 309.

94 IFC, Performance Standards on Environmental and Social Sustainability (2012).

95 ibid 2.

96 The Equator Principles, 'A Financial Industry Benchmark for Determining, Assessing and Managing Environmental and Social Risk in Projects' (2020) Available at $<$ https://equatorprinciples.com/wp-content/uploads/2020/05/The-Equator-Principles-July-2020-v2.pdf>.

97 IFC Performance Standard 1, at 7.

98 International Labour Organisation, Tripartite Declaration of Principles concerning Multinational Enterprises and Social Policy (5th edn, March 2017).

$99<$ https://www.ilo.org/empent/areas/mne-declaration/lang--en/index.htm>. 
concerning legal complicity in the context of international criminal law, relating to the standard of aiding and abetting. ${ }^{100}$ While questions of legal complicity may arise if an enterprise contributes to human rights breaches, the test for contribution is separate from, and broader than questions of legal complicity. ${ }^{101}$

That a contribution must be substantial was reiterated in the 2018 OECD Due Diligence Guidance for Responsible Business Conduct, promoting a common understanding of due diligence generally, ie across economic sectors. The Guidance aims to become the primary reference point for companies implementing HRDD. ${ }^{102}$ The Guidance establishes that a contribution must be substantial; this means that it does not include minor or trivial contributions. To assess whether a contribution is substantial, several factors matter, including the degree to which the activity increased the risk of the impact occurring; the degree of foreseeability; and the degree to which any of the enterprise's activities actually mitigated the adverse impact or decreased the risk of impact occurring. ${ }^{103}$ Despite previous efforts by the OECD and the OHCHR to coordinate definitions for the terms relating to attribution, ${ }^{104}$ it seems that both the OECD Garment Guidance and the general Due Diligence Guidance embrace a narrower approach to the identification of contribution. According to the UNGP, companies may prioritise and address substantial human rights impacts, but that does not affect their involvement. The OECD approach towards substantial contribution, and what seems like a de minimis test, could result in more limited grounds for the involvement of corporations in human rights impact under the OECD instruments.

ISO 26000 departs even more from the UNGP main features. As regards attribution, ISO 26000 at several critical junctures embraces a so-called 'sphere-of-influence' approach. The notion of sphere of influence originates in the failed attempt to adopt the Draft Norms on the Responsibilities of Transnational Corporations. ${ }^{105}$ It recognises that corporations have the ability to influence actions outside their own organisations through their relationships with other actors. ${ }^{106}$ Such influence would be greater in relation to actors in

\footnotetext{
$100 \mathrm{ie}$, 'knowingly providing practical assistance or encouragement that has a substantial effect on the commission of a crime'. United Nations Human Rights Office of the High Commissioner, 'The Corporate Responsibility to Respect Human Rights: An Interpretative Guide (2012) HR/PUB/12/ 02, at $5 . \quad 101$ See UNGP, commentary to Principle 17.

102 C Shavin, 'Unlocking the Potential of the New OECD Due Diligence Guidance on Responsible Business Conduct' (2019) 4 BHRJ 139.

103 OECD, Due Diligence Guidance for Responsible Business Conduct (2018) 70.

104 OECD 'Global Forum on Responsible Business Conduct: Expert Letters and Statements on the Application of the OECD Guidelines for Multinational Enterprises and UN Guiding Principles on Business and Human Rights in the Context of the Financial Sector' (26-7 June 2014, OECD Conference Centre, Paris).

105 Draft Norms on the Responsibilities of Transnational Corporations and Other Business Enterprises with regard to Human Rights: Draft Norms/ submitted by the Working Group on the Working Methods and Activities of Transnational Corporations pursuant to resolution 2002/8, E/CN.4/Sub.2/2003/12.

106 O de Schutter, 'The Challenge of Imposing Human Rights Norms on Corporate Actors' in $\mathrm{O}$ de Schutter (ed), Transnational Corporations and Human Rights (Hart Publishing 2006) 12.
} 
close proximity to the business entity in question. ${ }^{107}$ Under the Draft Norms, within their sphere of influence corporations have the obligation to promote, secure the fulfilment of, respect, ensure respect of, and protect human rights. ${ }^{108}$ This approach was expressly rejected by Ruggie on the ground that corporations need clearer and more precise guidance concerning their responsibilities. In Ruggie's view, the concept was problematic because imposing responsibility whenever a company has leverage would entail the assumption that 'can implies ought', and made it difficult to separate the duties and responsibilities of States and enterprises. Under their sphere of influence, companies would be responsible for human rights impacts of entities over which they may have some leverage, including cases where they are not contributing to, nor are a causal agent of, the negative human rights impact at hand. ${ }^{109}$ The rejection of this approach led to the adoption of the three categories discussed above, which centre on a corporation's network of business activities and relations, and its involvement in actual and potential impacts, rather than on the possibility of exerting leverage.

While elements of ISO 26000, despite not adopting the same terminology, are aligned with the spirit of the UNGP, ${ }^{110}$ the standard also embraces the concept of sphere of influence as well as taking a positive approach to business human rights responsibility in which corporations are expected to promote human rights where they have the influence to do so. ${ }^{111}$ Specifically concerning attribution, ISO 26000 provides that an organisation will be responsible for negative impacts committed by entities over which it has formal or factual control. In addition, it provides that a corporation may be capable of affecting the behaviour of entities within and beyond a value chain over which it has influence. However, the standard does not clarify what would be expected when there was such influence: the definition of sphere of influence does not imply a responsibility to exercise it. Furthermore, ISO 26000 does not necessarily consider that the entirety of an organisation's value chain falls within its sphere of influence. ${ }^{112}$ This stands in sharp contrast to the farreaching notion of direct linkage in the UNGP, which spans the entirety of a value chain. All in all, ISO 26000 resulted in considerable confusion concerning the actual responsibility of businesses and the attribution to businesses of human rights impacts committed by other entities. By mixing negative, positive, impact-based and leverage-based conceptions of responsibility, ${ }^{113}$ ISO does not clarify situations in which a corporation is

107 Special Representative of the Secretary General on Business and Human Rights, John Ruggie, "Clarifying the Concepts of "Sphere of Influence" and "Complicity": Report of the Special Representative of the Secretary-General on the Issue of Human Rights and Transnational Corporations and other Business Enterprises' (15 May 2008) UN Doc A/HRC/8/16.

108 Draft Norms, art A.1. 109 See (n 107) UN Doc A/HRC/8/16 at 5.

110 S Wood, 'The Case for Leverage-based Corporate Human Rights Responsibility' (2012) 22 Business Ethics Quarterly 70. 111 ISO 26000, Clause 4.8. 112 ibid, Clause 5.2.3.

113 Wood (n 110) 71. 
responsible for human rights impacts, and when influence/leverage should be exercised. ${ }^{114}$

In the IFC Performance Standards, the treatment of direct linkage to human rights impact also displays certain discrepancies from the UNGP. The IFC Performance Standards start by providing that clients 'should respect human rights, which means to avoid infringing on the human rights of others and address adverse human rights impacts business may cause or contribute to', ${ }^{115}$ with no mention of direct link. The standard then reduces the scope of application of due diligence to the specific projects financed, to be defined on a case-by-case basis with the lender, ${ }^{116}$ and its impacts as may be identified by the area of influence of the project. These include: the areas affected by the project and the client's activities and facilities that are directly owned, operated or managed and that are a component of the project; impacts from unplanned but predictable developments caused by the project that may occur later or at a different location; and indirect project impacts on biodiversity or on ecosystem services upon which affected communities' livelihoods are dependent. ${ }^{117}$ With respect to human rights impacts resulting from third party actions or omissions, the client is expected to address such impacts 'in a manner commensurate with the client's control and influence'. This seems in line with the idea that control and influence do not determine the existence of responsibility, but only how the company should discharge it. However, the Performance Standards provide that where control can be exercised, risks and impacts covered by management systems and due diligence also extends to those in the primary supply chain, ie that of goods or materials essential for the core business processes of the project. ${ }^{118}$ As the wording employed seems to suggests that control determines the scope of application and of responsibility, this approach seems incompatible with the UNGP.

The IFC Performance Standards also retain elements of the sphere of influence approach which was rejected by the UNGP, and they are not exclusively based on the presence of a business relationship. In addition, the Performance Standards limit the scope of due diligence in the value chains in two ways. Firstly, due diligence, and in particular human rights risk assessment, only covers suppliers and entities in the chain over which the client can exercise reasonable control. The concept of control establishes a rather high threshold, certainly higher than 'influence' and is different from 'business relations'. The concept itself represents an addition to the language in the UNGP. Secondly, the only value chain to be covered by HRDD only relates to products essential for the core business process of the project. This means that for business relations in other value chains there would be no

114 K Webb, 'ISO 26000 Social Responsibility Standard as "Proto Law" and a New Form of Global Custom: Positioning ISO 26000 in the Emerging Transnational Regulatory Governance Rule Instrument Architecture' (2015) 6 Transnational Legal Theory 466.

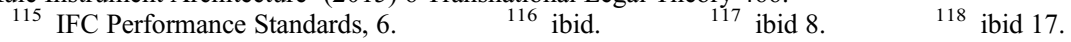


HRDD obligation. On the one hand, this narrower scope reflects the fact that the IFC Performance Standards also relate to the due diligence responsibilities of the lender in relation to projects being financed. Impacts outside such projects should not concern the lender as they would fall outside the scope of its business relationship with the client and thus lack a direct link. On the other hand, if the rationale behind the IFC Performance Standards is to manage environmental and social risks and impacts so that development opportunities are enhanced, ${ }^{119}$ singling out the value chains of the products essential for the core business process of the project is artificial and narrows the possible positive impacts of ensuring due diligence in the context of a loan.

Finally, the ILO tripartite Declaration of Principles concerning Multinational Enterprises and Social Policy was also revised in 2017 to incorporate the UNGP. ${ }^{120}$ As the instrument applies also to corporations, the latest revision introduced a general reference to the UNGP and to HRDD. These include the main features of HRDD (although no mention is made of reporting), and the three categories of attribution. ${ }^{121}$ Reference to the UNGP is then reiterated in the more detailed parts of the Declaration concerning areas such as employment and working conditions. For example, companies shall take action against child labour 'in their operations' in line with the notion of direct linkage, with, however, a qualification that such actions must fall 'within their competence'. It is possible that this phrasing could reduce the range of actions taken when exerting leverage. Leverage is not mentioned in the Declaration, except where it provides, rather restrictively, that multinationals should use their leverage to persuade their partners to provide remedies. ${ }^{122}$ We know from the UNGP that leverage should be exercised to address and mitigate impacts. As with the OECD Guidelines, the ILO Declaration has a mechanism for disputes concerning its application and interpretation and this also could contribute to differing interpretations of HRDD. ${ }^{123}$

\section{B. Explicit Resistance by Corporations: The Case of the Thun Group of Banks}

In addition to the work of international organisations, sectoral associations have also released documents and guidance for their members which seek to translate the UNGP into standards and practices within their sectors. ${ }^{124}$ The financial sector is crucial for the successful operationalisation of the corporate responsibility to respect human rights, in light of both the size of the sector,

119 ibid 2.

120 International Labour Organisation, ILO Tripartite Declaration of Principles concerning Multinational Enterprises and Social Policy (5th edn, March 2017).

122 ibid, para 65.

121 ibid, para 10 .

For another example: International Bar Association, 'Practical Guide on Business and Human Guide-Launch.aspx>. 
and its potential role as 'enabler' of human rights violations. The performance of banks with respect to human rights has considerable scope for improvement. ${ }^{125}$ However, given the various commercial relationships between banks and clients, as well as the variety and complexity of many financial instruments, transposing the UNGP to the financial sector is challenging. The financial sectors' attempts to do so have also resulted in the most explicit deviation from the concepts found in the UNGP, and an open challenge to them has been made.

The Thun Group of Banks, ${ }^{126}$ in a series of discussion papers published between 2013 and 2017, set out their common understanding of Principles 13 and 17, in particular focusing on the concept of 'direct link' to human rights risk. There has been some uncertainty in defining the boundaries of financial institutions' complicity (both in legal and non-legal terms) in human rights violations. ${ }^{127}$ The position taken by the banks limits the possibility of their being considered as causing or contributing to negative human rights impacts as a result of their commercial relations. The 2017 discussion paper clearly states that banks would generally not be considered to cause or contribute to adverse human rights impact arising from the operations of their clients, since such impact would not occur as part of the banks' own activities. ${ }^{128}$ The position of the Thun Group replaces two independent categories of attribution in the UNGP with their own specific requirements. Even more importantly, this approach means that banks can only be 'directly linked', and never be 'contributing' to human rights impacts. ${ }^{129}$ However, it is clear from the UNGP that situations where a company enables, encourages or facilitates other entities to harm human rights would be considered as a contribution.

In the Thun Group framework, direct linkage would occur only when specific financial products or services are delivered. Direct linkage is further limited by the introduction of the novel idea of a 'sufficient degree of linkage', or 'proximity', between the financial products and services offered and the

\footnotetext{
125 BankTrack, 'Banking with Principles? Benchmarking Banks Against the UN Guiding Principles on Business and Human Rights' (2016) available at <https://www.banktrack.org/ download/banking_with_principles>.

126 The Thun Group is an informal group of banks cooperating with the purpose of furthering understanding of the UNGP in the banking sector and how the UNGP may be applied across different banking activities. See Thun Group, Statement on the "Guiding Principles for the Implementation of the United Nations "Protect, Respect and Remedy" Framework on Human Rights' (19 October 2011).

${ }_{127}$ M Bordignon, 'The Compliance to Human Rights in Business Sector: Focusing on Banks' (2013) 1 Journal of Global Policy and Governance 217.

128 Thun Group of Banks, 'Paper on the Implications of UN Guiding Principles $13 \mathrm{~b}$ and 17 in a Corporate and Investment Banking Context' 6 . Available at $<$ https://www.business-humanrights. org/sites/default/files/documents/2017_12_Thun\%20Group\%20of\%20Banks_Paper_UNGP\% 2013 b\%20and \%2017.pdf>.

129 It should not be forgotten that, in case of direct link, no remediation is required.
} 
adverse impact. ${ }^{130}$ Proximity would allow a bank to assess and manage human rights risk. The 2017 discussion paper also introduces the concept of a unit of analysis, which would set the boundaries of the due diligence exercise and the emergence of a direct link. Asset-specific financing would require determining human rights impacts resulting from the use of that asset. More general corporate financing would require undertaking due diligence assessment of all the activities of the client. If human rights impacts were to occur within the appropriate unit of analysis, a bank would be directly linked to these impacts. ${ }^{131}$ This would remove the need to perform due diligence in relation to subsidiaries of parent companies, or parent companies of subsidiaries. However, the human rights risk flows from the relationship, rather than the type of product or service offered. ${ }^{132}$ Regardless of the type of financial product or service offered, financing the activities of an entity which is a high risk in terms of its likelihood of committing human rights violations granted in the absence of due diligence and strict conditionality, may result in a 'contribution', and not merely direct linkage.

\section{The Role of Ruggie, the Office of the High Commissioner for Human Rights, and Shift in Overseeing Interpretation}

It is important that when implementing and interpreting the UNGP, decentralised networks adhere to the spirit of the UNGP. When this does not happen, the interpretation offered by the networks must be 'steered' in the right direction. This steering function has been exercised by various actors such as the UN Office of the High Commissioner for Human Rights (OHCHR) and the UN Working Group on Business and Human Rights, but also the Shift Project-an NGO created by Ruggie to support the implementation and adoption of the UNGP — and by Ruggie himself. He has intervened in the global conversation concerning the UNGP on several occasions, both in his capacity as Special Representative and after his mandate formally ended in 2011 - in his personal capacity.

During his mandate, Ruggie became involved in the drafting of ISO 26000. Informal contacts between his team and the ISO Strategic Advisory Group took place $^{133}$ before Ruggie, more formally, voiced his concerns about the inclusion of the concept of 'sphere of influence' in the standard and the consequent inconsistency with the UNGP that it would generate. In a note, ${ }^{134}$ Ruggie highlighted the problems in embracing that approach and drew attention to his previous criticism of the concept in a preparatory report of the UNGP. ${ }^{135}$

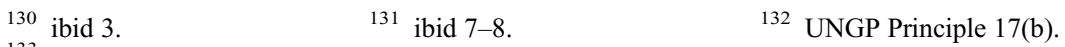

133 H Ward, 'The ISO 26000 International Guidance Standard on Social Responsibility: Implications for Public Policy and Transnational Democracy' (2011) 12 Theoretical Inquires in Law 695.

134 JG Ruggie, 'Note on ISO 26,000 Guidance Draft Document' (2009) Available at $<$ https:// www.business-humanrights.org/sites/default/files/media/documents/ruggie-note-re-iso-26000nov-2009.pdf $>$.

${ }^{135}$ Clarifying the concepts of 'sphere of influence' and 'complicity', A/HRC/8/16. 
The ISO Working Group on Social Responsibility redrafted the definition of sphere of influence and relevant articles in close cooperation with Ruggie's team, downplaying the connection between the possibility to influence and responsibility and stressing the concept of 'impact'. ${ }^{136}$ However, as discussed above, the idea of sphere of influence still permeates ISO 26000, and even suggests that business responsibility is not just negative but also positive, in express contradiction to the UNGP. ${ }^{137}$ As with other notes submitted by civil society and NGOs, such as WWF, the note submitted by Ruggie was formally accepted but only minimally reflected in the final text of ISO $26000 .{ }^{138}$

Ruggie was also in contact with the IFC and the OECD at various points. ${ }^{139}$ His contact with the OECD during the drafting of the 2018 Due Diligence Guidance for Responsible Business Conduct was particularly significant. Ruggie took issue with the notion of 'significant' or 'substantial' contribution to harm, discussed in Section III.A, noting the risk of employing language inconsistent with the UNGP, potentially undermining its spirit. ${ }^{140}$ Ruggie's criticism is based on a discussion paper prepared by the law firm Debevoise \& Plimpton on the three categories for attribution. ${ }^{141}$ In addition to using the term 'substantial contribution', Ruggie also criticised the idea that the concept of direct link and the presence of a business relation should be qualified by the presence of 'mutual commercial benefits'. ${ }^{142}$ The discussion paper equated direct link to the presence of a benefit to the company, a concept extraneous to the UNGP that limits the scope of attribution. While the notion of significant contribution was left in the final draft of the Guidance, no reference to the concept of 'mutual commercial benefit' can be found.

Ruggie also publicly commented on the Thun Group paper discussed in Section III.B and reiterated his concern with the introduction of language deviating from the UNGP. In a letter, Ruggie noted the misconstruction of UNGP 13 by collapsing 'cause' and 'contribution' into a single category, and the introduction of the term of 'proximity to harm'. ${ }^{143}$ Following Ruggie's intervention and NGOs pressure, the Thun Group slightly revised its position, conceding that banks could contribute to human rights impact 'under

\footnotetext{
136 Wood (n 110) 70.
}

137 ISO 26000, clause 4.1.

138 A Aseeva, 'Global Trade Governance and Informal Voluntary Standards: The Socionormative Analysis of Legitimacy of the ISO' in A Tutumlu and G Güngör (eds), Multilateralism in Global Governance; Formal and Informal Institutions (Peter Lang 2016) 91.

139 Buhmann (n 52) $426 . \quad{ }^{140}$ For Ruggie's letter see $<$ https://www.business-humanrights.org/ sites/default/files/documents/OECD\%20Workshop\%20Ruggie\%20letter\%20-\%20Mar\%202017_0. pdf $>$.

${ }^{141}$ Debevoise \& Plimpton and Enodo Rights. 'Practical Definitions of Cause, Contribute and Directly Linked to Inform Business Respect for Human Rights’ (2017) Available at <https://www. business-humanrights.org/sites/default/files/documents/Debevoise-Enodo-Practical-Meaning-ofInvolvement-Draft-2017-02-09.pdf>. 142 ibid $7-8$.

143 JG Ruggie, 'Comments on Thun Group of Banks Discussion Paper on the Implications of UN Guiding Principles $13 \& 17$ in a Corporate and Investment Banking Context' (2017) Available at $<$ https://www.business-humanrights.org/sites/default/files/documents/Thun\%20Final.pdf $>$. 
exceptional circumstances'. ${ }^{144}$ However, the paper failed to address the substance of Ruggie's criticism. In 2016 Ruggie also developed recommendations for FIFA to embed human rights in its global operations. ${ }^{145}$

Having received express requests on three occasions from the financial sector, the UN Office of the High Commissioner for Human Rights (OHCHR) has also offered (formally non-binding) interpretative clarifications concerning the UNGP and HRDD. Two requests made in 2013 covered the issue of minority shareholding, and specifically whether it could constitute a business relationship capable of giving rise to a direct link between a human rights impact and financial institutions. ${ }^{146}$ Having responded positively to this question, the two 2013 documents also accepted that project financing could amount to a direct link, something which is not supported by the text of the UNGP, and rejected the frequently employed terminology of 'indirect impact' or 'indirect link' (ie impacts caused by the client and not by the bank). In particular, it stressed that financing offered to a firm for a specific project would directly link a financial institution to all adverse human rights impacts generated by that project. ${ }^{147}$

Finally, in 2017, the OHCHR was approached by the NGO BankTrack for additional interpretative guidance following the Thun Group's paper. ${ }^{148}$ In its response, the $\mathrm{OHCHR}$ reiterated the distinction between contribution and direct link and noted that proximity was not a factor determining the boundaries of human rights responsibilities. It also noted that disputes about the presence of 'contribution' rather than 'direct link' could be settled through stakeholder dialogue or grievances processes, ${ }^{149}$ thereby identifying possible means of solving interpretative tensions. It should also be mentioned that the OHCHR published early interpretative guidance on the UNGP in $2012^{150}$ which, however, left several questions open, in particular on the concepts of attribution and leverage.

The UN Working Group on Business and Human Rights was established in the immediate aftermath of the UNGP, with its mandate extended in 2014 and 2017. Although not actively involved in interpreting UNGP, it has come to

144 Thun Group of Banks, 'Paper on the Implication of UN Guiding Principles 13b and 17 in a Corporate and Investment Banking Context' (2017) at 1. <https://www.business-humanrights.org/ sites/default/files/documents/2017_12_Thun\%20Group\%20of\%20Banks_Paper_UNGP\%2013b $\% 20$ and $\% 2017$.pdf $>$.

145 JG Ruggie, "For the Game. For the World." FIFA and Human Rights' Corporate Responsibility Initiative Report No 68 (Harvard Kennedy School, MA 2016).

${ }_{146}$ One is a response to a request made by the NGOs SOMO and OECD Watch: $<$ http://www. ohchr.org/Documents/Issues/Business/LetterSOMO.pdf $>$. The other is a response to a request by the OECD Working Group on Responsible Business Conduct: <https://www.ohchr.org/ Documents/Issues/Business/LetterOECD.pdf>.

147 See the response to the OECD Working Group on Responsible Business Conduct, at 5.

148 Available at $<$ https://www.ohchr.org/Documents/Issues/Business/InterpretationGuiding Principles.pdf $>$.

149 See the response to BankTrack, at 10.

150 United Nations Human Rights Office of the High Commissioner, 'The Corporate Responsibility to Respect Human Rights: An Interpretative Guide' (2012) HR/PUB/12/02. 
resemble an orchestrator that convenes and facilitates the work of other actors. ${ }^{151}$ Over the years, the UN Working Group has engaged with and supported a number of non-UN initiatives with the goal of achieving increased consistency, coordination and definitional clarity in the interpretations and understanding of the UNGP, while promoting dissemination and uptake. ${ }^{152} \mathrm{~A}$ key focus is to identify good practices while ensuring that the UNGP remain the authoritative reference point for business and human rights, and that various interpretative instruments do not undermine the integrity of the framework. ${ }^{153}$

A fourth actor playing a critical role in steering the interpretation of the UNGP, and in particular the concept of leverage, has been the Shift Project. Shift describes itself as the leading centre of expertise on the UNGP. Established by Ruggie in 2011, Shift's experts work in close contact with businesses, governments, civil society and international organisations to turn the UNGP into practice through education and training, advocacy and facilitation. ${ }^{154}$ Shift was among the first organisations to cooperate closely with business and has provided some pioneering guidance on the UNGP. Over time it has compiled a considerable number of documents, mostly in the form of guidelines to help business operationalise components of HRDD. A series of workshops with companies have contributed to clarify a number of practical elements of HRDD, including the embedding of human rights in corporate operations, ${ }^{155}$ the concept of 'direct link' and value chain due diligence, ${ }^{156}$ the use of leverage, ${ }^{157}$ and due diligence in high-risk circumstances. ${ }^{158}$

Even though its guidance documents can hardly be considered as soft law, the impact of Shift's work should not be underestimated. In particular, its work on leverage represents the first clarification offered on this critical concept based on

151 KW Abbott and D Snidal, 'Strengthening International Regulation through Transnational New Governance: Overcoming the Orchestration Deficit' (2009) 42 VandJTransnatlL 551.

152 MK Addo, 'The Reality of the United Nations Guiding Principles on Business and Human Rights' (2014) 14 HRLRev 133.

${ }^{153}$ UN Working Group on the Issue of Human Rights and Transnational Corporations and Other Business Enterprises, Report of the Working Group on the Issue of Human Rights and Transnational Corporations and Other Business Enterprises, Human Rights Council, UN Doc A/HRC/20/29 (10 April 2012) 11-12.

$154<$ https://www.shiftproject.org $>$.

155 Shift Project, 'Embedding Respect for Human Rights within a Company’s Operation' Shift Workshop Report No 1 (June 2012) available at <https://www.shiftproject.org/resources/ publications/embedding-respect-human-rights>.

156 Shift Project, 'Respecting Human Rights through Global Supply Chains' Shift Workshop Report No 2 (October 2012) available at <https://www.shiftproject.org/resources/publications/ respecting-human-rights-global-supply-chains $>$.

157 Shift Project, 'Using Leverage in Business Relationships to Reduce Human Rights Risks' (November 2013) available at <https://www.shiftproject.org/resources/publications/leveragebusiness-relationships-reduce-human-rights-risk/\#>.

${ }_{158}$ Shift Project, 'Human Rights Due Diligence in High-Risk Circumstances: Practical Strategies for Business' (March 2015) available at <https://www.shiftproject.org/resources/publications/ human-rights-due-diligence-high-risk-circumstances/>. 
corporate experience. ${ }^{159}$ The Guidance identifies five categories of leverage (traditional commercial leverage, business leverage, leverage with business partners, leverage through bilateral engagement, and through multistakeholder collaboration), with concrete examples and suggestions on how to identify opportunities and strategies. ${ }^{160}$ By cooperating with other actors, Shift has been able to spread this understanding of leverage to public bodies and international organisations. Guidance published with the Dutch Social and Economic Council, ${ }^{161}$ the European Commission, ${ }^{162}$ as well as by the International Labour Organisation and the International Organisation of Employers ${ }^{163}$ all reflect the approaches identified in Shift's workshops.

\section{THE THREAT OF POLYPHONY AND POSSIBLE SOLUTIONS}

The analysis above highlights considerable challenges in achieving consistent and fully aligned interpretation in an open polycentric regime where many actors can, and are in fact invited to, offer interpretation of key elements. The underlying idea behind the UNGP was to support and steer a process of bottomup emergence and convergence between various transnational regulatory regimes aiming at establishing human rights responsibility, bypassing States (and their disagreements). One of the purposes of the UNGP was to encourage rule emergence by and through interpretative intermediaries, ie to stimulate a global conversation on the principle of business respect for human rights. The UNGP have largely been successful on this front. Disseminating and embedding social norms is an indispensable method for inducing changes in conduct. ${ }^{164}$

The UNGP polycentric approach presents, however, its own risks, and these become clear where principles need to be refined and clarified through interpretation. An open polycentric system - characterised by the lack of barriers to expansive interpretations nor boundaries nor bodies that can officially reject 'deviant' interpretation-opens up the challenge of misaligned interpretations, and even interpretations which are contrary to the constitutive principles. Different intermediaries, while contributing to the assertion and institutionalisation of the general idea of corporate

\footnotetext{
159 Over time, additional clarifications emerged. For example, the OECD Guidances all contain examples of leverage in specific circumstances.

160 Shift Project (n 157) 6.

161 Shift Project, 'Business and Human Rights Impact: Identifying and Prioritising Human Rights Risks' Workshop Report (15-16 January 2014) Social and Economic Council (SER) The Hague. Available at $<$ https://www.shiftproject.org/resources/publications/business-human-rightsimpacts-identifying-prioritizing-risks/ $>$.

${ }^{162}$ European Commission, 'ICT Sector Guide on Implementing the UN Guiding Principles on Business and Human Rights' (2014). Available at $<$ https://publications.europa.eu/en/publicationdetail/-/publication/ab151420-d60a-40a7-b264-adce304e138b>.

163 ILO-IOE, 'Child labour guidance tool for business. How to do business with respect for children's right to be free from child labour. ILO International Programme on the Elimination of Child Labour; International Organisation of Employers (Geneva: ILO 2015). Available at $<$ https://www.unglobalcompact.org/library/3881>.

164 Ruggie (n 17).
} 
responsibility to respect human rights, also hinder the institutionalisation of some of the equally important details. This may occur because of intermediaries operating at different moments in time, on the basis of different organisational goals, or the use of different processes. More problematically, it also occurs because polycentricity - in the absence of clear interpretative responsibilities - enables powerful economic interests to undertake the fundamentally public functions of interpreting international soft law. Certain intermediaries arguably emerged in order to provide instrumental rule interpretation congenial to corporations, as it happens in the case of the Thun Group of Banks. Alignment of the intermediaries' goals with those of the principal regime is crucial in determining how they will fulfil their intermediary function. International organisations whose mandate is close to the UNGP goals generate fewer discrepancies. 'Obstructionists' that intervene arguably to frustrate the goals of the regime generate substantial deviation. 165

In this 'polyphonic' scenario, where no organisation or actor can claim interpretative monopoly over the language in the UNGP, rule creators must attempt to retain or regain control over the interpretation of the rules in question, ${ }^{166}$ and steer intermediates towards consistency. The lack of a body with a clear coordinating role has meant that various actors have attempted to steer intermediaries. Their degree of success varies, highlighting the difficulty of steering other regulatory actors towards a desired outcome. Interpretation provided by these 'steering actors' does not adhere to the traditional methods of interpreting the law, such as linguistic, systemic, and teleological interpretative techniques. This is quite striking considering that, in the end, the UNGP constitute international law, however soft.

Apart from the uncontroversial role of the OHCHR in providing interpretative guidance, albeit non-binding, Ruggie's interventions are arguably made possible because of the moral authority he continues, and decides, to exercise as 'creator' of the UNGP. That Ruggie sees himself as a main architect behind the UNGP is clear from his writings, ${ }^{167}$ and from his limited receptivity to input concerning possible changes to the core concepts of the framework. ${ }^{168}$ The centralising effect of Ruggie's interventions and his position as the 'main creator' are difficult to reconcile with the UNGP' focus on polycentricity, pluralism and consultation. The additional reliance on Shift, established by Ruggie as a centre of expertise on the UNGP, is a creative attempt to insulate the code from other influences and to develop it in accordance with its founding principles through multi-stakeholder workshops

165 L Brès, S Mena and ML Salles-Djelic, 'Exploring the Formal and Informal Roles of Regulatory Intermediaries in Transnational Multistakeholder Regulation' (2019) 13 RegGov 133.

${ }^{166} \mathrm{P}$ Goodrich, Reading the Law: A Critical Introduction to Legal Method and Techniques (Basil Blackwell 1984) 123.

167 '... the Guiding Principles on Business and Human Rights that I developed ...', emphasis added, Ruggie (n 5) 5.

168 Deva (n 67) 85-6. 
and consensus. In spite of this unconventional approach, the interpretative work of Shift has been widely accepted and is now reflected in guidance documents produced by public authorities and international organisations. Attempts at steering are, then, grounded on rationales as diverse as the formal authority of the OHCHR, the moral authority of Ruggie and, in line with bottom-up processes underlying the emergence of the UNGP, the involvement of corporations and other stakeholders.

It is difficult to pinpoint the underlying reasons for deviations and discrepancies between the approaches of international organisations. As suggested earlier, different actors operate on the basis of distinct organisational goals, and draft their standards involving specific groups and on the basis of their own procedures. In this light, a certain degree of variation would be difficult to avoid. Inclusive participation is not the rule, as the limited stakeholder participation in ISO 26000 drafting demonstrates, ${ }^{169}$ and as evidenced by the Thun Group approach, which has involved only business actors. A decentralised process of interpretation (and implementation) cannot ensure that the inclusive process that led to the adoption of the UNGP can be successfully replicated. Quite the opposite, inclusiveness may be more of an obstacle to the formation of detailed rules than it is to the adoption of broad principles, or may contribute to the emergence of particular interpretations. Further research is needed, but this may occur because of internal disagreement or because, when operating by consensus, the temptation may be either to avoid the more controversial issues, or to settle for the less ambitious positions advanced by of businesses.

The analysis illustrates that polycentric regimes relying on the interpretative work of multiple intermediaries and the lack of an authority to challenges 'deviant' interpretation are exposed to the risk of a lack of consistency when it comes to detail. Empirically, considerable divergence is possible, as ISO 26000 demonstrates. While polycentricity has been instrumental in establishing business responsibility to respect human rights, deviations in interpretation and polyphony could undermine rule acceptance. In particular, they may hinder the establishment and institutionalisation of the responsibility itself and a consistent message about the boundaries of such responsibility, as corporations shop around for interpretations that better suit their interests.

Where intermediaries have divergent goals, regulators should intervene in their activities and centralise their functions. ${ }^{170}$ In the case of the UNGP an organisation responsible for interpretative work could be designated, leaving

169 R Hahn and C Weidtmann, 'Transnational Governance, Deliberative Democracy, and the Legitimacy of ISO 26000: Analyzing the Case of a Global Multistakeholder Process' (2016) 55 Business \& Society 90. See also Aseeva (n 138).

${ }^{170}$ N De Silva, 'Intermediaries Complexity in Regulatory Governance: The International Criminal Court's Use of NGOs in Regulating International Crimes' (2017) 670 AnnalsAmAcadPol\&SocSci 170. 
implementation and operationalisation of management processes to other actors with no 'barriers to entry'. Currently, the OHCHR provides non-binding interpretations, but has done so only in the few cases in which it was requested to intervene. A possible solution would be to have national courts or OECD National Contact Points taking up interpreting functions. ${ }^{171}$ Even if national courts themselves produce differing interpretations, the transnational nature of much business activity means that corporations tend to adopt the approach found in the most restrictive jurisdiction in which they work, and this can have an 'aligning' effect. Courts decisions could also influence guidance issued by organisations such as the OECD.

It would however be preferable if centralised interpretive functions were exercised by international courts and tribunals or international organisations. The possible adoption of a binding treaty on business and human rights may return some interpretive functions to bodies traditionally entrusted with that role. A Zero Draft submitted in 2017 to the Open-ended Intergovernmental Working Group on Transnational Corporations and Other Business Enterprises with Respect to Human Rights attracted considerable criticism. ${ }^{172}$ The goals of a possible Treaty are to strengthen respect of human rights in business activities, prevent human rights violations and ensure access to remedies. The Revised Draft submitted in July 2019 makes the connection with the UNGP more explicit and includes an obligation for States to introduce mandatory HRDD legislation. ${ }^{173}$ The Draft is better aligned to both the spirit and the language of the UNGP than was the Zero Draft. ${ }^{174}$ However, the text refers to 'abuses that may arise from their own business activities, or from their contractual relationships'. It must be noted that direct linkage encompasses situations connected to business relationships, which is a broader concept than merely contractual relationships. On a more positive note, the Revised Draft expressly enumerates the components of HRDD as specified in the UNGP.

The Revised Draft offers various venues for interpretation. First, it specifies States where alleged violations have occurred, victims are domiciled, or natural

171 HH Koh, 'Transnational Public Law Litigation' (1991) 100 YaleLJ 2347.

172 D Cassel, 'The Third Session of the UN Intergovernmental Working Group on a Business and Human Rights Treaty’ (2018) 3 BHRJ 277.

173 Open-ended Intergovernmental Working Group on Transnational Corporations and Other Business Enterprises with Respect to Human Rights. Revised Draft, art 5. Available at $<$ https:// www.ohchr.org/Documents/HRBodies/HRCouncil/WGTransCorp/OEIGWG_RevisedDraft_LBI. pdf>.

${ }^{174}$ Holding, with respect to the categories of attribution, that corporations should exercise due diligence with respect to their own activities, those of entities under direct and indirect control, and those directly linked to its operations, products or services. Open-ended Intergovernmental Working Group on Transnational Corporations and Other Business Enterprises with Respect to Human Rights. Zero Draft, art 9. Available at <https://www.business-humanrights.org/sites/default/files/ documents/DraftLBI.pdf>. 
or legal persons involved are domiciled, all have jurisdiction over claims. ${ }^{175}$ This approach increases the possibility of national litigation concerning the meaning and boundaries of HRDD, which could foster consistency and uniformity. Another option for decentralised interpretation would be the Draft Optional Protocol, ${ }^{176}$ establishing a National Implementation Mechanism responsible for the promotion and implementation of the Treaty. Among other objectives, the national body would be entrusted with review functions and of making recommendations concerning corporate operationalisation of HRDD practices, including that of single corporations. Remarkably, and most promisingly, centralised interpretation is provided for in the Revised Draft itself. Parties to the Treaty may agree to submit to the International Court of Justice (ICJ) disputes concerning the interpretation of the Treaty which cannot be solved by non-judicial means. ${ }^{177}$ Although in its current form the provision does not grant compulsory jurisdiction to the ICJ, it would make possible the unequivocal interpretation of the categories of attribution and other matters left open by the UNGP Framework.

A possible Binding Treaty should, however, go much further establish a body which has the authority to provide binding interpretations of the UNGP. It could have the power to respond to requests for interpretation, or even do so proprio motu should it consider that guidance issued by intermediaries, or even national courts, was not in accordance with the UNGP. This would not undermine the progress made through the UNGP, the acceptance of HRDD and its interpretation in various fora. Decentralised interpretation, in line with polycentricity, would be retained. It could, however, offer a much-needed institutional complement to the UNGP polycentric approach that is indispensable both for cementing the responsibility to respect human rights, as well as providing guidance to businesses in the operationalisation of their responsibilities.

\section{CONCLUSION}

Polycentric structures help ensure both norm diffusion and implementation by decentralised networks. However, in the field of business and human rights an appraisal of the regulatory governance of the UNGP reveals challenges in interpretation and ensuring consistency concerning approaches to attribution.

Remarkably, these challenges derive from the very governance arrangements chosen as an alternative to traditional legal instruments to establish and refine

\footnotetext{
175 Open-ended Intergovernmental Working Group on Transnational Corporations and Other Business Enterprises with Respect to Human Rights. Revised Draft, art 7.

176 Open-ended Intergovernmental Working Group on Transnational Corporations and Other Business Enterprises with Respect to Human Rights. Draft Optional Protocol. Available at $<$ https:// www.ohchr.org/Documents/HRBodies/HRCouncil/WGTransCorp/Session4/ZeroDraftOPLegally. pdf $>$.

177 Open-ended Intergovernmental Working Group on Transnational Corporations and Other Business Enterprises with Respect to Human Rights. Revised Draft, art 16.2.
} 
corporate responsibility to respect human rights. While polycentricity has been instrumental to the diffusion and acceptance of the corporate responsibility to respect, it also risks degenerating into polyphony given the lack of centralised interpretative authority. It is therefore suggested that the informal mechanisms currently used for guiding the interpretation of key elements of the UNGP are supported by more formal institutions which are able to provide final and authoritative interpretations when necessary. This would act as a guard against interpretations being inappropriately influenced by the economic interests of those currently engaging in interpretive activities.

Drawing on the literature on regulation, this article has argued that it is crucial that detailed interpretive guidance is provided to multinationals, and that uncontested and clear Principles are needed in order to establish the corporate responsibility to respect. The polycentric structure of the UNGP, almost ten years since its establishment, has been successful in affirming and diffusing the corporate responsibility to respect. We are now entering a stage where due diligence is about to become 'mainstream', with a growing number of companies actively supporting the introduction of mandatory HRDD legislation, and where precise and consistent guidance is needed. Corporations must receive unequivocal guidance about the boundaries of their responsibility to respect. The threats posed by HRDD's indeterminate framework and obligations should not be underestimated, and are similar to the wild proliferation of 'sustainability' claims in the past decades. ${ }^{178}$ Similarly to the many private standards addressing sustainability in production practices that appeared in recent times, it is possible to make claims concerning the proper undertaking of due diligence by corporations, that may in fact be disconnected from actual positive impact. There is thus a risk that due diligence could similarly result in extensive 'greenwashing' and 'bluewashing' of corporate activities, as well as forum shopping for less ambitious HRDD standards and guidelines that better suit the businesses in question. ${ }^{179}$

Centralising interpretation is necessary in order to address and avoid conflicting approaches to operationalising HRDD and, ultimately, for embedding respect for human rights in corporate activities. It is consistent with the legal pluralism of the business and human rights field and is an essential and indispensable component of effective polycentric regimes. Adding this missing element to the informal structure of the UNGP would allow public authorities to effectively intervene in conflicts between public and private orders through the provision of 'formal' interpretation, and to manage tensions between, and align, the various conflicting instruments.

\footnotetext{
178 A Marx and J Wouters, 'Competition and Cooperation in the Market of Voluntary Sustainability Standards' in Delimatsis (n 93) 215.

179 E Partiti, 'Orchestration as a Form of Public Action: The EU Engagement with Voluntary Sustainability Standards’ 25 ELJ 115-16.
} 